\title{
ERRATUM
}

\section{Erratum to: Starting Insulin in Type 2 Diabetes: Real-World Outcomes After the First 12 Months of Insulin Therapy in a New Zealand Cohort}

Shekhar Sehgal · Manish Khanolkar

To view enhanced content go to www.diabetestherapy-open.com

Published online: February 27, 2015

(C) The Author(s) 2015. This article is published with open access at Springerlink.com

Erratum to: Diabetes Ther

DOI 10.1007/s13300-015-0100-8

In the Introduction, the sentence "The IDF guidelines recommend starting with a longacting basal insulin analog, with pre-mixed insulin for those with higher HbA1C" should read:

"The IDF guidelines recommend starting with a long-acting basal insulin, and suggest starting with pre-mixed insulins for those with a higher starting HbA1C."

The Conflict of interest section should read:
Manish Khanolkar has consulted in an advisory capacity and recieved speaker's fees for Eli Lilly, Sanofi Aventis and Novo Nordisk. Shekhar Sehgal declares that he has no conflict of interest.

Open Access. This article is distributed under the terms of the Creative Commons Attribution Noncommercial License which permits any noncommercial use, distribution, and reproduction in any medium, provided the original author(s) and the source are credited.

The online version of the original article can be found under doi:10.1007/s13300-015-0100-8.

S. Sehgal $(\bowtie)$

Diabetes and Endocrinology registrar, Department of Endocrinology and Diabetes, Waikato Hospital, Hamilton, New Zealand

e-mail: shrike59@gmail.com

M. Khanolkar

Greenlane Clinical Centre, 1142 Auckland,

New Zealand

e-mail: ManishK@adhb.govt.nz 